\title{
AN OVERVIEW OF COLORECTAL CANCER: IMPLICATION OF TWO MEDICINAL PLANTS IN THEIR TREATMENT
}

\author{
JYOTHI BASINI ${ }^{1 *}$, SIREESHA RAYADURGAM ${ }^{2}$, SWETHA DAKSHINAMURTHY ${ }^{1}$
}

${ }^{1}$ Department of Pharmacology, Seven Hills College of Pharmacy, Tirupati, Andhra Pradesh, India. ${ }^{2}$ Department of Pharmaceutical Analysis, Seven Hills College of Pharmacy, Tirupati, Andhra Pradesh, India. Email: jyothi_811@yahoo.co.in

Received: 30 March 2019, Revised and Accepted: 28 May 2019

\begin{abstract}
Nowadays, cancer is one of the most common diseases in humans. Among all types, colorectal cancer (CRC) is one of the most serious types diagnosed in men after lung and prostate cancer while in women it occupies the second position after breast cancer worldwide. The risk factors such as obesity, sedentary lifestyle, bad nutritional habits (high in fats and proteins), smoking, and progressive aging are the cause of CRC. The acquisition of abnormal mutations leads to a consisting of many different arrangements of events during the tumor development process. Over the years, different approaches have been employed, in the treatment of cancer. These include chemotherapy, radiotherapy, surgery, and immunotherapy. Chemotherapy is routinely used for cancer treatment, but the toxicity of chemotherapeutics on healthy cells of the human body is obvious. This is the reason for discovering the new, natural origin, substances with potential cytostatic effects and less toxic side effects on the healthy cells. Medicinal plants have a special place in the management of cancer. Numerous cancer research studies have been conducted using traditional medicinal plants to discover new therapeutic agents with fewer side effects. In this review, we are describing two medicinal plants such as Actiniopteris radiata (Sw.) Link (Mayurashikha) and Terminalia pallida Brandis (Tella karaka) (endemic plant) which are available immensely in Chittoor District are used till today by the traditional herbal practitioners, tribal people is near to Talakona forest and Ayurvedic people for various diseases and also for CRC.
\end{abstract}

Keywords: Colorectal cancer, Risk factors, Pathogenesis, Treatment, Medicinal plants

(C) 2019 The Authors. Published by Innovare Academic Sciences Pvt Ltd. This is an open access article under the CC BY license (http://creativecommons. org/licenses/by/4. 0/) DOI: http://dx.doi.org/10.22159/ajpcr.2019.v12i6.33287

\section{INTRODUCTION}

Colorectal cancer (CRC) is the fourth most common type of cancer in the world, with 1.3 million new cases each year and a 5-year prevalence rate of 3.2 million cases [1,2]. In 2012, there were an estimated 693,333 deaths due to CRC. The prevalence of CRC is higher in developed countries than in developing and undeveloped nations. Adults greater than 50 years are more prone to be affected by CRC, and incidence in males is greater than in females [3]. The CRC incidence and percentage vary from one place to another place in all over the world. In India, the incidence is higher in males; it is the fifth most common cancer following breast, cervix/uteri, lip/oral cavity, and lung cancer [1].

CRC is cancer that starts in either colon or rectum. It usually starts as a polyp in the intestinal mucosa exists as an initial benign lesion called adenoma that can transform into a malignant lesion depending on its histological presentation, and its size, of which $60 \%$ of cases are simple adenoma, and $40 \%$ are multiple adenomas. About $24 \%$ of patients with untreated polyps will develop cancer [4].

The clinical presentation of CRC depends on the location, size, as well as the presence or absence of metastasis. The symptoms include abdominal pain, alteration of chronic bowel habits, changes in bowel movements, involuntary weight loss, nausea, vomiting, malaise, anorexia, and abdominal distension [5]. Distal cancers cause evident rectal bleeding in comparison to proximal cancer that can give mixed blood with stool, so it tends to occulted, and in consequence, anemia may be presented as a secondary sign.

\section{RISK FACTORS}

The risk factors responsible for CRC are diet and westernized lifestyle; there is no specific food or another environmental agent that has been identified as an exact causative factor [6].
CRC identified types are hereditary nonpolyposis, familial adenomatous polyposis, inflammatory bowel diseases [7-10], human papillomaviruses, and acquired immunodeficiency syndrome [11]. Approximately 20\% of CRC cases are associated with familial clustering, and patients with colorectal adenomas or invasive CRC are at increased risk for CRC [12-15].

The different lifestyle factors are associated with development of CRC including high alcohol consumption (60\%) [16], high-fat diet poor in fiber, red meat, obesity, smoking (20\%), lack of physical exercise [17], diabetes [18], older age, and family history (20\%) [19]

\section{STAGES OF COLORECTAL CANCER}

CRC is classified under the Astler-Coller-Dukes system or tumor, node, and metastasis system established by the American Joint Committee on Cancer [20], which represents the stages of CRC by categories. The letter $\mathrm{T}$ represents the spread of tumors through the layers of the colonic or rectal wall, the letter $\mathrm{N}$ indicates if there is the propagation of tumors in the lymph node, and $M$ indicates metastasis to distant organs [21]. The $\mathrm{T}, \mathrm{N}$, and $\mathrm{M}$ scores are combined to assign the CRC stages. There are five stages and they are numbered like I (1), II (2), III (3), or IV (4) (Table 1).

\section{PATHOGENESIS}

The bases of CRC hallmarks are genomic instability and inflammation. Genomic instability confers random mutations including chromosomal rearrangements, mutation errors in DNA, genes involved in the control of the cellular cycle, repair, and apoptosis or mutations in tumor suppressor gene such as adenomatous polyposis coli (APC), deleted in CRC (DCC), B-Raf proto-oncogene (BRAF), phosphatidylinositol-4, 5-bisphosphate 3-kinase catalytic subunit alpha (PIK3CA), protein kinase $\mathrm{B}$, and tumor protein (TP53) or the presence oncogenes as Kirsten rat sarcoma (K-ras), and Catenin Beta 1, while the inflammatory state of premalignant and malignant lesions that are driven by cells of the immune system also fosters multiple hallmark functions [3]. 
Fearon and Vogelstein hypothesized that colorectal carcinogenesis is a multistep process in which genes are mutated in a specific order [22], resulting in the transition from normal mucosa to benign adenoma to severe dysplasia to carcinoma. The first in this process is the loss of APC tumor suppressor gene, which results in loss of DCC gene and activation of K-ras oncogene. This is followed by the inactivation of p53, leading to eventual carcinoma formation. This is in agreement with Knudson's two-hit theory in which the carcinogenesis process is thought to result from an accumulation of two or more mutations that affect cell cycle control aberrations or other features of neoplastic development [23].

- First, the inactivation or alteration of the APC gene, i.e., tumor suppressor gene can lead to the activation of the Wingless-type pathway, a common mechanism for initiating polyp to cancer progression sequence [24]

- Second, mutations of oncogenes, K-ras virus oncogene homolog or B-Raf proto-oncogene, aberrantly activating the mitogenactivated protein kinase signaling pathway leads to increase cell proliferation [25,26]

- Third, the inactivation of the DCC gene is a late event in the carcinogenesis of CRC and has a role in metastasis [27]

- Lastly, $P^{53}$ is a tumor suppressor (transcriptional factor) that controls the cell cycle, apoptosis, and DNA repair mechanisms [28]. Hence, P53 mutations or the loss of its functionality and the frequency of alterations in the gene increases with the corresponding progression of the lesion [29].

Finally, the inflammatory proteins such as cyclooxygenase-2 (COX-2), inducible nitric oxide synthase (iNOS), and Cyclin D1 over expression lead to colorectal carcinogenesis

\section{DIAGNOSIS}

Current screening methods are targeted toward moderate risk population aged 50 or more [32].

- Medical history: The causes of CRC are unknown. By collecting the medical history of a patient include disease conditions/and certain medications, long-term usage lead to CRC will help to predict the causes of CRC

- Example: (a) Lynch syndrome also called hereditary nonpolyposis colon cancer is an inherited syndrome and familial adenomatous polyposis is a rare inherited syndrome that often leads to CRC

- Physical exam: Along with taking medical history, it is also important to examine the patient's physical parameters to know about functions for the sign of disease

- Example: Body temperature, blood pressure, pulse rate, and respiration rate

Table 1: Tumor, node, and metastasis classification and stages of colorectal cancer

\begin{tabular}{llll}
\hline AICC stage & TNM stage & \multicolumn{2}{c}{ TNM stage criteria for colorectal cancer } \\
\hline Stage I & T1 N0 M0 & T1 & Tumor invades submucosa \\
Stage I & T2 N0 M0 & T2 & Tumor invades muscularis mucosa \\
Stage II-A & T3 N0 M0 & T3 & Tumor invades subserosa or beyond \\
Stage II-B & T4 N0 M0 & T4 & Tumor invades adjacent organs or perforates the visceral peritoneum \\
Stage III-A & T1-2 N1 M0 & N1 & Metastasis to 1 to 3 regional lymph nodes. T1 or T2 \\
Stage III-B & T3-4 N1 M0 & N2 & Metastasis to 1 to 3 regional lymph nodes. T3 or T4 \\
Stage III-C & Any T, N2 M0 & M1 & Metastasis to 4 or more regional lymph nodes. Any T \\
Stage IV & Any T, any N, M1 & & Distant metastases present. Any T, any N \\
\hline
\end{tabular}

TNM: Tumor, node, and metastasis

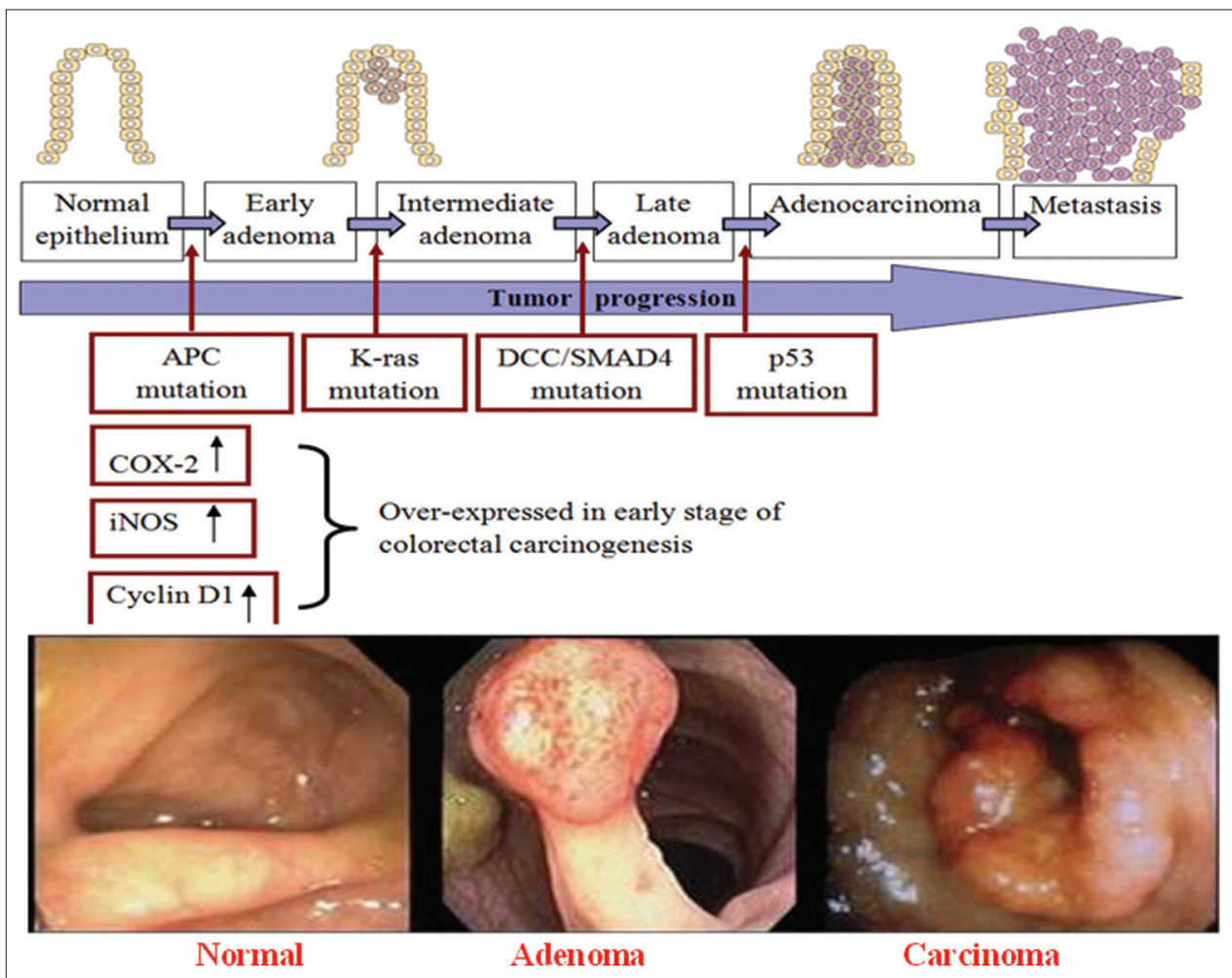

Fig. 1: Colorectal cancer is a multi-step process in which genes are mutated in a specific sequence $[30,31]$ 


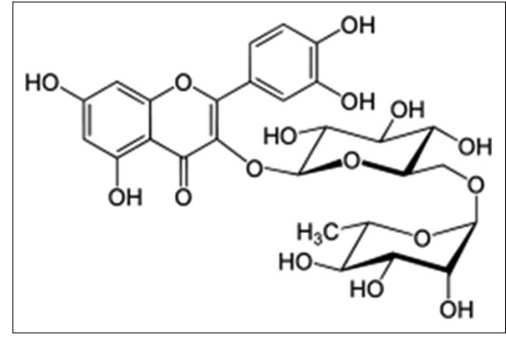

Fig. 2: Structure of Rutin-flavonoid glycoside (quercetin-3rutinoside)
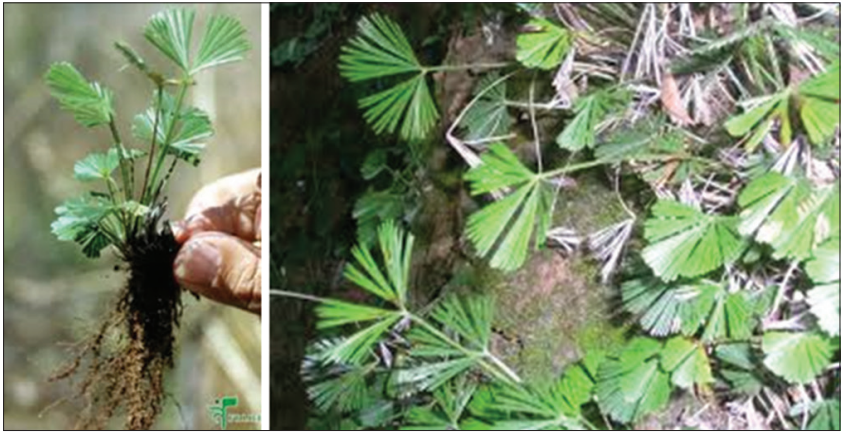

Fig. 3: Actiniopteris radiata (Sw.) Link (Mayurashikha)
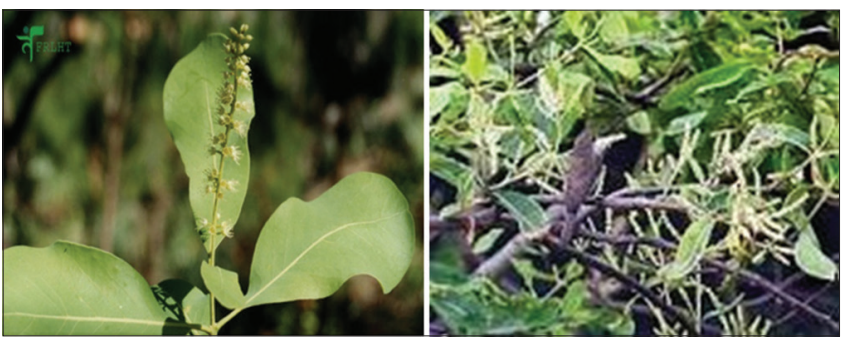

Fig. 4: Terminalia pallida Brandis (Tella karaka) (Endemic plant)

- Total colonoscopy: It is a procedure in which the morphology of large intestine can be examined. This study helps in finding out the growth of polyps and any other disease related to the colon

- Blood tests: These are used to evaluate the disease by estimating biochemical parameters. (i) Complete blood count measures the number of blood cells in a sample and (ii) chemistry profile-CRC spreads cause high or low levels of chemicals in the blood

- Example: High carcinoembryonic antigen level

- Imaging tests: (i) Computerized tomography (CT) with contrast-CT takes many pictures a body part using X-rays, (ii) magnetic resonance image-uses a magnetic field and radio waves to take pictures, and (iii) positron emission tomography/CT-scan can show tumor size and also can find whether a tumor is a metastasis or not

- Needle biopsy: Samples of tissue or fluid removed from the body with a needle sent to a pathologist for cancer testing by performing the RAS mutation test, $v$-Raf murine sarcoma viral oncogene homolog B mutation test, and mismatch repair protein (MMR), or microsatellite instability test

- Immunochemistry panel is used to assess MMR proteins.

\section{TREATMENT}

The treatment for CRC depends on whether the disease is nonmetastasis or metastasis. The mainstay curative treatment for patients with nonmetastasized tumors is surgery. However, the outcome is strongly related to the quality of surgery $[33,34]$ the quality of preoperative staging and treatment selection. Local recurrences after the colon and rectal surgery can be minimized using short-course radiotherapy [35-37], although long-term therapy showed no effect on overall survival for this approach [38]. Neoadjuvant radiotherapy/chemoradiotherapy) can be proposed for patients with unfavorable T3 rectal tumors. The chemotherapy backbone for first-line treatment of metastatic disease is typically a combination of leucovorin, 5-fluorouracil, and either oxaliplatin or irinotecan (Adjuvant chemotherapy) [39]. Some of the researchers have focused on this adjuvant chemotherapy drugs to overcome therapy resistance, reduce dose requirements, drug-induced adverse effects and increase cytotoxic effects using histone deacetylase inhibitors (Vorinostat, romidepsin, panobinostat, and belinostat) [40]. These treatment methods are not as effective in treating cancer cases in the metastasis stage. Cancer treatment failure, through chemotherapy, can happen because of the low selectivity of the cytotoxic and uncertainty of the molecular targeted [41]. Chemotherapy can put the patient under a lot of strain and further damage their health. Hence, many of the researchers have to focus on using alternative therapies against cancer with low side effects.

Nowadays, the most important problem in cancer treatment is destroying tumor cells in the presence of natural cells, without damaging natural cells. To prepare anticancer medicines from natural resources such as plants, testing cytotoxic compounds, and screening raw extracts of plants are necessary [42]. Therefore, the availability of natural products with higher effectiveness and lower side effects is desired [43]. Medicinal herbs are important for cancer treatment due to their multiple chemical compounds for discovering new active materials against cancer [44]. These compounds are called secondary metabolites. Alkaloids, terpenoids, flavonoids, pigments, and tannins are important constituents of these compounds. Secondary metabolites have biologic effects such as anti-inflammatory, anticancer, contraceptive, and different effects on hematopoietic cells [45], lipids [46], and cardiovascular systems [47]. Different improvements are reported in common treatments of cancer by finding secondary compounds of natural products and medicinal herbs. It is believed that anticancer effects of plants develop by suppressing cancer's stimulating enzymes, repairing DNA, stimulating the production of antitumor enzymes in the cell, increasing body immunity, and inducing antioxidant effects $[48,49]$.

The different researches and studies have been proved the positive effect of plants in curing diabetes, fertility, and sterility, thyroid disorders, anemia, psychological disorder, etc. Finding plants that replace chemotherapy and cumbersome cures of cancer with cytotoxic effects are necessary.

In this review, we chose Actiniopteris radiata and Terminalia pallida ayurvedic plants to describe the mechanism of action for the treatment of CRC. Mayurashikha (A. radiata) is an ayurvedic herb and a tiny terrestrial fern found throughout India. It is also called as Peacock's tail. A. radiata (Sw.) Link. belonging to the family Polypodiaceae. It is also found in different places such as Burma, Sri Lanka, Afghanistan, Persia, Arabia, Yemen, South Eastern Egypt, Tropical Africa, Australia, and Madagascar. The whole part of the plant is used in wounds, intestinal worms as a cooling agent in syphilis, rickettsiae, piles, leukorrhea, typhoid [50], cough, high blood pressure, tuberculosis, asthma, fever, leprosy, and hair growth [51]. The leaves of the plant are used for aphrodisiac [52], to increase the potency in women [52-54], as leukorrhea, as fertility [55,56], in irregular menstrual period, for conception, and birth control [51]. The stem of this plant is used in diarrhea [56,57].

The chemical constituents such as flavonoid glycoside (Quercetin3 -rutinoside), steroidal compounds ( $\beta$-sitosterol, $\beta$-sitosterol palmitate, and $\beta$-sitosterol-D-glucoside), alkane hydrocarbon chains (hentriacontane and hentriacontanol) [58], and glycosides (2-(3, 4-0-diglucos cinnamoyl)- 4- hydroxyl furan and 1-Heptaloyl, 8-hexyl, 3-(0-diglucos), 10-methyl, 9, 10-dihydro naphthalene) are used [59]. The other constituents are glucose, fructose, flavonoids, alkaloids, tannins, phenols, saponins, quinines, terpenoids, coumarins, $\beta$-cyanin, and triterpenoids [60]. 
The plant extract possesses different research activities such as analgesic activity [61], antihistaminic and anti-cholinergic activity [62], antifertility [63], antitubercular [64], antibacterial [65], anthelmintic [66], antifungal [67], wound healing [61], antistress and antiallergic effects [68], antioxidant and radical scavenging activity [69,70], hepatoprotective activity [71] diuretic, antiinflammatory, and antidiabetic activity [72]

T. pallida Brandis is herb from the family Combretaceae. It is a semievergreen tree group. Leaf fall and flushing events occur during the pre-monsoon season; leaf flushing extends into the monsoon season. The flowers are bisexual and obligately outcrossed and enforced by self-incompatibility. Fruits fall to the ground when mature and dry in the presence of wind. The fallen fruits are scattered by rainwater, and the seeds germinate and establish seedlings depending on the soil status [73]. It is one of the oldest medicinal herbs of India, which is an ingredient of Indian Ayurvedic drug "Triphala" used for the treatment of digestion and liver disorders. In Indian traditional system of medicine, the fruits are also used in the treatment of hepatic disorders and the treatment of diabetes by tribal people [74]. The leaf is used for treating skin blisters and skin diseases, whereas the stem bark is used as a diuretic and for swellings. The fruit is used as an anti-pyretic, purgative, for diarrhea, peptic ulcers, diabetes, venereal diseases, cough, cold, dysentery, fissures, and cracks; and in tanning and dying. Bark powder is applied externally and can be taken internally as an anti-inflammatory agent. Fruit powder is given orally to cure peptic ulcer fissure and to clear the harshness of voice [75-77].

The reported biological activities of Terminalia pallida such as antioxidant activity and hepatoprotective potential [78], analgesic and anti-pyretic activity [75], anti-diabetic activity [76], anti-atherogenic and anti-hyperlipidemic activities of fruits [77], anti-ulcer activity [79], anti-bacterial activity [80], phytochemical evaluation and antimicrobial studies [81]. This plant has many important phytoconstituents such as gallotannic acid, bellericanin, gallic acid, ellagic acid, termilignan, thannin lignin, flavones and anolignan $\mathrm{B}$, tannins, ethyl gallate, ellagic acid, gallonyl glucose, and chebulagic acid, phenyllemblin, betasitosterol, mannitol, rhamnose, and glucose [75-77,79,81]

Medicinal plants are representing a wide variety of phytochemicals with pharmaceutical potential such as phenolic acids, flavonoids, steroids, terpenoids, and triterpenoids. Polyphenols such as flavonoids and phenolic acids have been reported to have many pharmacological activities, such as antioxidant, anti-inflammatory, anticarcinogenic, antiviral, or anti-allergic effects [82-86]. Among anticancer and cancer-preventing drugs, flavonoids are the most studied ones. These compounds can interfere with specific stages of the carcinogenic process, inhibit cell proliferation, and induce apoptosis in several types of cancer cells [87-91]. Flavonoids exhibit a good antioxidant activity by inhibiting reactive oxygen species generation/affecting the activity of sundry detoxifying enzymes, such as COXs, Lipoxygenases, and iNOS [92-94]. This antioxidant capacity of flavonoids could possibly account for their anticancer potency. Flavonoids have also been found to influence epigenetic alterations by chromatin remodeling $[95,96]$. Hashemzaei et al., 2017 [81], were reported and proved that quercetin (belongs to polyphenolic flavonoid) is a potent anticancer agent in in vitro and in vivo cancer studies. In particular, it has been reported that quercetin at various concentrations, suppresses tumor growth of various cancer cell lines, including breast, colorectal, stomach, head and neck, lung, ovarian, melanoma, and leukemia [97-107]. Mayurashikha contains major phytoconstituent is rutin (Quercetin-3-glycoside) [58] and T. pallida with a major constituent is phenolic acids [81]. Due to the presence of phytoconstituents, in these plants may show the antioxidant and anticancer property that happens maybe by inducing apoptosis initiation, ATP-dependent chromatin remodeling, reduce COX-2 overexpression and DNA methylation, histone modification, inhibition of misregulation of miRNA, and tumor angiogenesis and also can modify the different cellular signaling pathways involved in cell proliferation
The above two medicinal plants will be the plan to do research work for anti-CRC activity in vitro and in vivo cancer models.

\section{CONCLUSION}

CRC is a leading problem globally, especially in developing countries and also in developed countries because many of the people migrated from village to town; changing their lifestyles and food habits. Majority food intake and lifestyle habits are the risk factors for the development of cancer in the colon. Management of CRC by surgery followed adjuvant therapy (Radiotherapy and chemotherapy) produce high toxic effects which can be minimized with supplementation of medicinal plants (Ayurveda). Medicinal plants have a major role in the treatment of different ailments like cancer because they have major nutritive values and antioxidant properties. Mayurashikha (A. radiata) and T. pallida Brandis are two medicinal plants with specific active constituents that may show anti-CRC property.

\section{AUTHORS' CONTRIBUTIONS}

Jyothi Basini, Sireesha Rayadurgam, and Swetha Dakshinamurthy have contributed for review article preparation and editing of the manuscript.

\section{COMPETING INTERESTS}

The authors declare that there are no conflicts of interest.

\section{REFERENCES}

1. Ferlay J, Steliarova-Foucher E, Lortet-Tieulent J, Rosso S, Coebergh JW, Comber $\mathrm{H}$, et al. Cancer incidence and mortality patterns in Europe: Estimates for 40 countries in 2012. Eur J Cancer 2013;49:1374-403.

2. Bray F, Ren JS, Masuyer E, Ferlay J. Global estimates of cancer prevalence for 27 sites in the adult population in 2008. Int J Cancer 2013;132:1133-45

3. Alam MN, Almoyad M, Huq F. Polyphenols in colorectal cancer: Current state of knowledge including clinical trials and molecular mechanism of action. Biomed Res Int 2018;2018:4154185.

4. DeVita V, Lawrence T, Rosenberg S. Cancer: Principles and Practice of Oncol. $9^{\text {th }}$ ed. Philadelphia: Lippincott Williams and Wilkins; 2011.

5. Calva AM, Acevedo Tirado MT, Revision Y. Actualization general en cancer colorectal. Rev Radiol Mexico 2009;1:99-115.

6. Potter JD. Colorectal cancer: Molecules and populations. J Natl Cancer Instit 1999;91:916-32.

7. Terzić J, Grivennikov S, Karin E, Karin M. Inflammation and colon cancer. Gastroenterology 2010;138:2101-14.

8. Beaugerie L, Svrcek M, Seksik P, Bouvier AM, Simon T, Allez M, et al. Risk of colorectal high-grade dysplasia and cancer in a prospective observational cohort of patients with inflammatory bowel disease. Gastroenterology 2013;145:166-75.

9. Johnson CM, Wei C, Ensor JE, Smolenski DJ, Amos CI, Levin B, et al. Meta-analyses of colorectal cancer risk factors. Cancer Causes Control 2013;24:1207-22.

10. Lutgens MW, van Oijen MG, van der Heijden GJ, Vleggaar FP, Siersema PD, Oldenburg B, et al. Declining risk of colorectal cancer in inflammatory bowel disease: An updated meta-analysis of populationbased cohort studies. Inflamm Bowel Dis 2013;19:789-99.

11. Ponz de Leon M, Benatti P, Borghi F, Pedroni M, Scarselli A, Di Gregorio C, et al. Aetiology of colorectal cancer and relevance of monogenic inheritance. Gut 2004;53:115-22.

12. Ahsan H, Neugut AI, Garbowski GC, Jacobson JS, Forde KA, Treat MR. Family history of colorectal adenomatous polyps and increased risk for colorectal cancer. Ann Intern Med 1998;128:900-5.

13. Bonelli L, Martines H, Conio M, Bruzzi P, Aste H. Family history of colorectal cancer as a risk factor for benign and malignant tumours of the large bowel. A case-control study. Int J Cancer 1988;41:513-7.

14. Hemminki K, Eng C. Clinical genetic counselling for familial cancers requires reliable data on familial cancer risks and general action plans. J Med Genet 2004;41:801-7.

15. Hemminki K, Chen B. Familial risk for colorectal cancers are mainly due to heritable causes. Cancer Epidemiol Biomarkers Prev 2004;13:1253-6.

16. Huxley RR, Ansary-Moghaddam A, Clifton P, Czernichow S, Parr CL, Woodward M. The impact of dietary and lifestyle risk factors on risk of colorectal cancer: A quantitative overview of the epidemiological 
evidence. Int J Cancer 2009;125:171-80.

17. Watson AJ, Collins PD. Colon cancer: A civilization disorder. Dig Dis 2011;29:222-8

18. Meyerhardt JA, Catalano PJ, Haller DG, Mayer RJ, Macdonald JS, Benson $\mathrm{AB} 3^{\text {rd }}$, et al. Impact of diabetes mellitus on outcomes in patients with colon cancer. J Clin Oncol 2003;21:433-40.

19. Johns LE, Houlston RS. A systematic review and meta-analysis of familial colorectal cancer risk. Am J Gastroenterol 2001;96:2992-3003.

20. Silva AC, Hara AK, Leighton JA, Heppell JP. CT colonography with intravenous contrast material: Varied appearances of colorectal carcinoma. Radiographics 2005;25:1321-34.

21. Granados-Romero JJ, Valderrama-Trevino AI, Contreras-Flores EH, Barrera-Mera B, Enriquez MH, Uriarte-Ruiz K, et al. Colorectal cancer: A review. Int J Res Med Sci 2017;5:4667-76.

22. Fearon ER, Vogelstein B. A genetic model for colorectal tumorigenesis. Cell 1990;61:759-67.

23. Knudson AG. Two genetic hits (more or less) to cancer. Nat Rev Cancer 2001;1:157-62.

24. Vogelstein B, Fearon ER, Hamilton SR, Kern SE, Preisinger AC, Leppert $\mathrm{M}$, et al. Genetic alterations during colorectal-tumor development. N Engl J Med 1988;319:525-32.

25. Samowitz WS, Albertsen H, Herrick J, Levin TR, Sweeney C, Murtaugh MA, et al. Evaluation of a large, population-based sample supports a $\mathrm{CpG}$ island methylator phenotype in colon cancer. Gastroenterology 2005;129:837-45.

26. Nosho K, Irahara N, Shima K, Kure S, Kirkner GJ, Schernhammer ES, et al. Comprehensive biostatistical analysis of $\mathrm{cpG}$ island methylator phenotype in colorectal cancer using a large population-based sample. PLoS One 2008;3:e3698.

27. Kato K, Matsuda M, Ingu A, Imai M, Kasai S, Mito M. Colon cancer with a high serum alpha-fetoprotein level. Am J Gastroenterol 1996;91:1045-6.

28. Rodrigues NR, Rowan A, Smith ME, Kerr IB, Bodmer WF, Gannon JV, et al. P53 mutations in colorectal cancer. Proc Natl Acad Sci U S A 1990;87:7555-9.

29. Takaku K, Oshima M, Miyoshi H, Matsui M, Seldin MF, Taketo MM. Intestinal tumorigenesis in compound mutant mice of both DPC4 (Smad4) and APC genes. Cell 1998;92:645-56.

30. Baldassarre G, Belletti B, Nicoloso MS, Schiappacassi M, Vecchione A, Spessotto P, et al. P27(Kip1)-stathmin interaction influences sarcoma cell migration and invasion. Cancer Cell 2005;7:51-63.

31. Green JE, Hudson T. The promise of genetically engineered mice for cancer prevention studies. Nat Rev Cancer 2005;5:184-98.

32. National Comprehensive Cancer Network Guidelines (NCCN Guidelines). Colorectal Cancer Screening. Washington: NCCN Guidelines; 2014.

33. Jeffery M, Hickey BE, Hider PN. The Cochrane Database of Systematic Reviews. Hoboken, N.J.: John Wiley \& Sons, Ltd.; 1996.

34. Primrose JN, Perera R, Gray A, Rose P, Fuller A, Corkhill A, et al. Effect of 3 to 5 years of scheduled CEA and CT follow-up to detect recurrence of colorectal cancer: The FACS randomized clinical trial. JAMA 2014;311:263-70.

35. Martin-Perez B, Andrade-Ribeiro GD, Hunter L, Atallah S. A systematic review of transanal minimally invasive surgery (TAMIS) from 2010 to 2013. Tech Coloproctol 2014;18:775-88.

36. Nagtegaal ID, Marijnen CA, Kranenbarg EK, van de Velde CJ, van Krieken JH; Pathology Review Committee. Circumferential margin involvement is still an important predictor of local recurrence in rectal carcinoma: Not one millimeter but two millimeters is the limit. Am J Surg Pathol 2002;26:350-7.

37. Quirke P, Steele R, Monson J, Grieve R, Khanna S, Couture J, et al. Effect of the plane of surgery achieved on local recurrence in patients with operable rectal cancer: A prospective study using data from the MRC CR07 and NCIC-CTG CO16 randomised clinical trial. Lancet 2009;373:821-8.

38. Heald RJ, Husband EM, Ryall RD. The mesorectum in rectal cancer surgery - the clue to pelvic recurrence? Br J Surg 1982;69:613-6.

39. Mohelnikova-Duchonova B, Melichar B, Soucek P. FOLFOX/FOLFIRI pharmacogenetics: The call for a personalized approach in colorectal cancer therapy. World J Gastroenterol 2014;20:10316-30.

40. Al-Keilani MS, Alsmadi DH. The HDAC inhibitor sodium phenylbutyrate enhances the cytotoxicity by 5 -fluorouracil, oxaliplatin, and irinotecan in colorectal cancer cell lines. Int J Pharm Pharm Sci 2018;10:155-9.

41. Mutiah R, Sukardiman, Widyawaruyanti A. Cytotoxic effect of crude extract and fraction from Calotropis gigantea leaves on human colon cancer widr cell lines. Int J Pharm Pharm Sci 2017;9:83-6.

42. Rafieian-Kopaie M, Nasri H. On the occasion of world cancer day 2015; the possibility of cancer prevention or treatment with antioxidants: The ongoing cancer prevention researches. Int J Prev Med 2015;6:108

43. Lachenmayer A, Alsinet C, Chang CY, Llovet JM. Molecular approaches to treatment of hepatocellular carcinoma. Dig Liver Dis 2010;42 Suppl 3:S264-72.

44. Newman DJ, Cragg GM. Natural products as sources of new drugs over the last 25 years. J Nat Prod 2007;70:461-77.

45. Mansouri E, Kooti W, Bazvand M, Ghasemi Boroon M, Amirzargar A, Afrisham R, et al. The effect of hydro-alcoholic extract of Foeniculum vulgare mill on leukocytes and hematological tests in male rats. Jundishapur J Nat Pharm Prod 2015;10:e18396.

46. Kooti W, Ghasemiboroon M, Asadi-Samani M, Ahangarpoor A, Ahmad Abadi MN, Afrisham R, et al. The effects of hydro-alcoholic extract of celery on the lipid profile of rats fed a high-fat diet. Adv Environ Biol 2014;8:325-30.

47. Kooti W, Hasanzadeh-Noohi Z, Sharafi-Ahvazi N, Asadi-Samani M, Ashtary-Larky D. Phytochemistry, pharmacology, and therapeutic uses of black seed (Nigella sativa). Chin J Nat Med 2016;14:732-45.

48. Sakarkar DM, Deshmukh VN. Ethnopharmacological review of traditional medicinal plants for anticancer activity. Int J Pharm Tech Res 2011;3:298-308.

49. Kooti W, Servatyari K, Behzadifar M, Asadi-Samani M, Sadeghi F, Nouri B, et al. Effective medicinal plant in cancer treatment, part 2: Review study. J Evid Based Complementary Altern Med 2017;22:982-95.

50. Porte SM. Overview of folk medicine used for Typhoid in India. Int J Res Ayurveda Pharm 2014;5:219-24

51. Pingale Shirish S, Deokar Dinesh E, Punde Vikas M. Recent developments in Actiniopteris radiata. Int Res J Sci Eng 2018;A3:165-72.

52. Singh S, Singh R. Ethnomedicinal use of pteridophytes in reproductive health of tribal women of pachmarhi biosphere reserve, Madhya Pradesh, India. Int J Pharm Sci Res 2012;3:4780-90.

53. Gupta RS, Sharma R. Review on medicinal plant exhibiting antifertility activity in male. Natl Prod Radiance 2006;5:389-410.

54. Singh S, Singh R. Utilization of pteridophyte of AchanakmarAmarckantak biosphere reserve, central India in women's health and beauty care practices. Int Res J Pharm 2013;4:235-40.

55. Nyarko HD, Victor YA, Batama BJ. Antimicrobial examinations of Cymbopogon citratus and Adiatum capillusveneris used in Ghanaian folkloric medicine. Int J Life Sci Res 2012;2:L115-8.

56. Santhosh Kumar S, Samydurai P, Nagarajan N. Indigenous knowledge on some medicinal pteridophytic plant species among the Malasar Tribe's in Valparai Hills, Western Ghats of Tamil Nadu. Am J Ethnomed 2014; $1: 164-73$

57. Revathi R, Muthuraja R, Thomas B, Raju K. Ethnomedicinal fern and fern-allies used by tribe Malayalis of Kolli Hills, Eastern Ghats, Tamil Nadu. Pteridol Res 2013;2:1-10.

58. Hemalatha K, Sunandana Rao N, Shivaji N. Phytochemical constituents of Actiniopteris radiata Linn. Whole plant. Ann Phytomed Int J 2012;1:34-8.

59. Narasimhaiah L, Chandrasekhar MJ, Alexander S. Isolation of new glycosides from pteridophyte plant. Int J Pharm Pharm Sci 2012;4:615-7.

60. Rajesh KD, Vasantha S, Rajesh NV, Panneerselvam A. Qualitative and quantitative phytochemical analysis in four pteridophytes. Int J Pharm Sci Rev Res 2014;27:408-12.

61. Ramalingeswara Reddy P, Sreenivasulu M, Chand Basha S. Actiniopteris radiata (linn.): A comprehensive review. J Global Trends Pharm Sci 2012;3:612-8

62. Alai VR, Vadnere GP. In vitro Antihistaminic and anticholinergic activity of Actiniopteris radiata (Sw.) Link. on isolated rat ileum. Int J Pharmtech Res 2011;3:5-7.

63. Dixit SK, Bhatt GK. Folk-lore studies on unknown indigenous antifertility drugs. J Res Ind Med 1975;10:77-81

64. Munna S, Chand Basha S, Ramalingewara Reddy P, Pramod N, Pradeep Kumar Y, Mahaboob Basha G. The antitubercular activity of Actiniopteris radiata Linn. J Global Trends Pharm Sci 2014;5:1443-5.

65. Moorthy D, Paulsamy S, Nandha Kumar K, Saradha M. In vitro antibacterial activity of the fern, Actiniopteris radiata (Sw.) Link. inhabiting the Shervaroyan Hills, the Eastern Ghats. J Chem Pharm Res 2013;5:211-4

66. Sreenivasulu V, Chand Basha S, Adinarayan Y, Lingaswam V, Praveen Kumar UN. Anthelmintic activity of Actiniopteris radiata (linn.). J Global Trends Pharm Sci 2014;5:1716-8.

67. Naik JB, Jadege DR. Antibacterial and antifungal activity of Actiniopteris radiata (Sw.) Link. International Journal of PharmTech Research 2010;2:1751-3.

68. Vadnere GP, Pathan AR, Songhai AK, Kulkarni BU, Hundiwale JC. Anti-stress and anti-allergic effect of Actiniopteris radiata in some 
aspects of asthma. Pak J Pharm Sci 2013;26:195-8

69. Manjunath M, Lavanya G, Sivajyothi R, Reddy OV. Antioxidant and radical scavenging activity of Actiniopteris radiata (Sw.) link. Asian J Exp Sci 2011;25:73-80.

70. Paulsamy S, Moorthy D, Nandakumar K, Saradha M. Evaluation of in vitro antioxidant potential of methanolic extracts of the ferns, Actiniopteris radiata (sw) link. and Equisetum ramosissimum desf. Int J Res Dev Pharm Life Sci 2013;3:451-5.

71. Naga Sravanthi K, Rajeshwara Rao P, Niranjan J. Hepatoprotective activity of ethanolic extract of Actiniopetris radiata Linn against ccl4 induced hepatotoxicity in Wistar albino rats. Int J Res Pharmacol Pharmacother 2012;1:201

72. Naik B, Jadge DR, Deshpande AN, Gadgul AB, Siddiqui AR. Pharmacological and phytochemical review on Actiniopteris radiata. Int J Pharm Sci Res 2017;4:1373-7.

73. Solomon Raju AJ, Vara Lakshmi P, Venkata Ramana K. Department of Environmental Sciences. Andhra University, Visakhapatnam, India; 2019.

74. Chattopadhyay RR, Bhattacharyya SK. Terminalia chebula: An update. Pharmacogn Rev 2007;1:151-6.

75. Shaik HA, Eswaraih MC, Lahari M, Maruthi Rao B, Ali SF. Evaluation of analgesic and anti-pyretic activities of ethanolic extract of Terminalia pallida (EETP) stem in experimental animals. Sch J Appl Med Sci 2013;1:5-8

76. Kameswara Rao B, Renuka Sudarshan P, Rajasekhar MD, Nagaraju N, Appa Rao C. Antidiabetic activity of Terminalia pallida fruit in alloxan induced diabetic rats. J Ethnopharmacol 2003;85:169-72.

77. Sampathkumar MT, Kasetti RB, Nabi SA, Sudarshan PR, Swapna S, Apparao C. Antihyperlipidemic and antiatherogenic activities of Terminalia pallida linn. Fruits in high fat diet-induced hyperlipidemic rats. J Pharm Bioallied Sci 2011:3:449-52.

78. Palani S, Raja S, Venkadesan D, Karthi S, Sakthivel K, Senthil Kumar B. Antioxidant activity and hepatoprotective potential of Terminalia pallida. Arch Appl Sci Res 2009;1:18-28.

79. Gupta M, Mazumder UK, Manikandan L, Bhattacharya S, Senthilkumar GP, Suresh R, et al. Anti-ulcer activity of ethanol extract of Terminalia pallida brandis. in swiss albino rats. J Ethnopharmacol 2005;97:405-8

80. Gupta M, Mazumder UK, Manikandan L, Bhattacharya S, Haldar PK, Roy S, et al. Antibacterial activity of Terminalia pallida. Fitoterapia 2002;73:165-7.

81. Rajasekhar K, Reddy R, Raju V. Phytochemical evaluation and antimicrobial studies on Terminalia pallida Brandis (Combretaceae) A rare and endemic medicinal plant. Int J Pharm Res Dev 2013;5:40-4.

82. Hashemzaei M, Barani AK, Iranshahi M, Rezaee R, Tsarouhas K, Tsatsakis AM, et al. Effects of resveratrol on carbon monoxide-induced cardiotoxicity in rats. Environ Toxicol Pharmacol 2016;46:110-5.

83. Hashemzaei M, Entezari Heravi R, Rezaee R, Roohbakhsh A, Karimi G. Regulation of autophagy by some natural products as a potential therapeutic strategy for cardiovascular disorders. Eur J Pharmacol 2017;802:44-51.

84. Hashemzaei M, Sadeghi Bonjar MA, Tabrizian K, Iranshahi M, Iranshahy M, Rezaee R. Evaluation of the analgesic effect of Umbelliprenin and Umbelliprenin-morphine co-administration on the acute, chronic and neuropathic pain. Indian J Pharm Educ Res 2015;49:121-5.

85. Kumar S, Pandey AK. Chemistry and biological activities of flavonoids: An overview. ScientificWorldJournal 2013;2013:162750.

86. Tabrizian K, Yaghoobi NS, Iranshahi M, Shahraki J, Rezaee R, Hashemzaei M. Auraptene consolidates memory, reverses scopolaminedisrupted memory in passive avoidance task, and ameliorates retention deficits in mice. Iran J Basic Med Sci 2015;18:1014-9.

87. Nikitovic D, Tsatsakis AM, Karamanos NK, Tzanakakis GN. The effects of genistein on the synthesis and distribution of glycosaminoglycans/ proteoglycans by two osteosarcoma cell lines depends on tyrosine kinase and the estrogen receptor density. Anticancer Res 2003;23:459-64

88. Yamaguchi M, Murata T, El-Rayes BF, Shoji M. The flavonoid p-hydroxycinnamic acid exhibits anticancer effects in human pancreatic cancer MIA paCa-2 cells in vitro: Comparison with gemcitabine. Oncol Rep 2015;34:3304-10.

89. Cárdenas M, Marder M, Blank VC, Roguin LP. Antitumor activity of some natural flavonoids and synthetic derivatives on various human and murine cancer cell lines. Bioorg Med Chem 2006;14:2966-71.

90. Chan FL, Choi HL, Chen ZY, Chan PS, Huang Y. Induction of apoptosis in prostate cancer cell lines by a flavonoid, baicalin. Cancer Lett 2000;160:219-28.

91. Kawaii S, Tomono Y, Katase E, Ogawa K, Yano M. Antiproliferative activity of flavonoids on several cancer cell lines. Biosci Biotechnol Biochem 1999;63:896-9.

92. Lin P, Tian XH, Yi YS, Jiang WS, Zhou YJ, Cheng WJ. Luteolininduced protection of $\mathrm{H}_{2} \mathrm{O}_{2}$-induced apoptosis in PC12 cells and the associated pathway. Mol Med Rep 2015;12:7699-704.

93. Leung HW, Kuo CL, Yang WH, Lin CH, Lee HZ. Antioxidant enzymes activity involvement in luteolin-induced human lung squamous carcinoma CH27 cell apoptosis. Eur J Pharmacol 2006;534:12-8.

94. Wu TH, Yen FL, Lin LT, Tsai TR, Lin CC, Cham TM, et al. Preparation, physicochemical characterization, and antioxidant effects of quercetin nanoparticles. Int J Pharm 2008;346:160-8.

95. Busch C, Burkard M, Leischner C, Lauer UM, Frank J, Venturelli S. Epigenetic activities of flavonoids in the prevention and treatment of cancer. Clin Epigenetics 2015;7:64

96. Gilbert ER, Liu D. Flavonoids influence epigenetic-modifying enzyme activity: Structure - Function relationships and the therapeutic potential for cancer. Curr Med Chem 2010;17:1756-68.

97. Deng XH, Song HY, Zhou YF, Yuan GY, Zheng FJ. Effects of quercetin on the proliferation of breast cancer cells and expression of survivin in vitro. Exp Ther Med 2013;6:1155-8.

98. Ren KW, Li YH, Wu G, Ren JZ, Lu HB, Li ZM, et al. Quercetin nanoparticles display antitumor activity via proliferation inhibition and apoptosis induction in liver cancer cells. Int J Oncol 2017;50:1299-311.

99. Chen J, Kang JH. Quercetin and trichostatin A cooperatively kill human leukemia cells. Pharmazie 2005;60:856-60.

100. Priego S, Feddi F, Ferrer P, Mena S, Benlloch M, Ortega A, et al. Natural polyphenols facilitate elimination of HT-29 colorectal cancer xenografts by chemoradiotherapy: A Bcl-2- and superoxide dismutase 2-dependent mechanism. Mol Cancer Ther 2008;7:3330-42.

101. Scambia G, Ranelletti FO, Panici PB, De Vincenzo R, Bonanno G, Ferrandina G, et al. Quercetin potentiates the effect of adriamycin in a multidrug-resistant MCF-7 human breast-cancer cell line: P-glycoprotein as a possible target. Cancer Chemother Pharmacol 1994;34:459-64.

102. Yoshida M, Sakai T, Hosokawa N, Marui N, Matsumoto K, Fujioka A, et al. The effect of quercetin on cell cycle progression and growth of human gastric cancer cells. FEBS Lett 1990;260:10-3

103. Sharma $H$, Sen S, Singh N. Molecular pathways in the chemosensitization of cisplatin by quercetin in human head and neck cancer. Cancer Biol Ther 2005;4:949-55.

104. Yang JH, Hsia TC, Kuo HM, Chao PD, Chou CC, Wei YH, et al. Inhibition of lung cancer cell growth by quercetin glucuronides via $\mathrm{G} 2 / \mathrm{M}$ arrest and induction of apoptosis. Drug Metab Dispos 2006;34:296-304.

105. Gao X, Wang B, Wei X, Men K, Zheng F, Zhou Y, et al. Anticancer effect and mechanism of polymer micelle-encapsulated quercetin on ovarian cancer. Nanoscale 2012;4:7021-30.

106. Cao HH, Tse AK, Kwan HY, Yu H, Cheng CY, Su T, et al. Quercetin exerts anti-melanoma activities and inhibits STAT3 signaling. Biochem Pharmacol 2014;87:424-34

107. Spagnuolo C, Russo M, Bilotto S, Tedesco I, Laratta B, Russo GL. Dietary polyphenols in cancer prevention: The example of the flavonoid quercetin in leukemia. Ann N Y Acad Sci 2012;1259:95-103. 